\title{
W. B. L.
}

\section{A. W. D. LEISHMAN}

AFTER 39 years memory for the average man is for the most part a blur with only isolated points of good definition and unhappily a youth of 19 . of no great sensibility cannot be counted the keenest of observers. Sad to say also the period of observation available to myself was scarcely more than 13 years. The earliest association with my father that I now recall was when we lived at Leatherhead and concerns an Empire Day ceremony at a local school where he addressed the children and took the salute at a march-past while his son aged, I judge, 5 or 6 clad in a sailor suit assisted in the raising of the Union Jack on the flag pole.

By this time he had already achieved distinction and had been knighted for his discovery of the protozoon responsible for kala-azar and it has long been my regret that I did not share in the excitements of that early rise to fame. My father married comparatively late in life and there was thus a rather larger than usual disparity of years between father and son for he was about 48 at the time to which I refer and I have no memory of other than a middle aged man. He had I understand been a keen and proficient yachtsman, a good shot and swimmer in his younger days but now, apart from an occasional game of golf played with remarkably ancient clubs, athletic pursuits were abandoned and he turned mainly to gardening for his recreation. From Leatherhead he travelled daily to London where at this time he held the Army Chair of Pathology until this was interrupted in a year or two by the start of the 1914-18 war and I have then a vivid and undoubted memory of the family admiring and helping to clean his sword as father prepared to leave for France as Colonel and Adviser in Pathology to the British Expeditionary Force.

There were now four children, three girls from 11 to a baby of 1 and myself aged 7 and the educational facilities and relative safety provided by Eastbourne led my mother to transport the family to a series of temporary homes in this town for the duration of the war. Now followed at inevitably long intervals no more than glimpses of father at leave periods; a separation from his family which was alleviated by his capacity for letter writing for he found time for almost daily letters to my mother and by no means infrequently wrote to us children. These letters were invariably full of humour and effectively concealed from us the more unpleasant aspects of his life in France.

With the conclusion of the war and his appointment as Director of Pathology at the War Office the family returned to suburban life this time to Croydon which offered the advantage of an exceptional train service to London. Here in a not unattractive typically middle class suburban house with a moderate sized garden he lived for 8 years till his death and inevitably it is of this period that my personal recollection of my father is the most acute.

Although we were now in the "twenties" our home environment seems at this distance to have retained features of the Edwardian era and while we were by no means in awe of our parent it was understood and accepted that father the great man must be

FOOTNOTE: AUSTIN -WILLIAM DREVAR LEISHMAN, M.A:, D.M., F.R.C.P. Cons. Phys. United Sheffield Hospitals and Doncaster Gate Hospital, Rotherham; sometime Lieutenant-Colonel R.A.M.C. 
protected from us children. After a day's work in town he would retire each evening to his study busying himself with papers he had usually brought home with him and $I$ have rather few recollections of him indulging in light reading or other relaxations. Often evening engagements in Londón would keep him late and as I lay in bed I would hear him return by horse-cab which from compassion for the few remaining and ageing cabbies he invariably chose in preference to a taxi to bring him home from the station, for we had no car. On occasions also the slightly embarrassed but resplendent figure of a Major General (later Lieutenant General) complete with cocked hat and festooned with decorations would astonish the citizens of East Croydon as he made his way humbly by suburban train to some function in town.

In the holidays when back from school we met at meal times and we stole in quietly at bedtime to say goodnight but it was only at the weekend that we could get to know him. For father the weekend meant gardening and this seemed to provide him with the relaxation he greatly needed for by nature I sensed he was a worrier. The R.A.M.C. was I believe then going through a particularly difficult time, failing to attract the best recruits and he was greatly concerned for its future, but he worried also I know a good deal about personal finance. He had little more than his Army pay and we three elder children latterly at least were an expensive luxury for I spent 5 years at his old school (Westminster) and three of us were sent to University, two of us going to Oxford. To do this undoubtedly demanded a considerable personal sacrifice as well as very careful management on the part of my mother who was well trained to this role being herself a member of the large family of an Army Colonel.

As for all children the annual summer holiday was the outstanding event of the year not. least perhaps because father at last could be seen at close quarters. Until the early war years our holidays were invariably spent in Scotland at the family home at Blairmore on the shores of Loch Long. Here lived my grandmother and my father's two unmarried sisters (my grandfather, the Regius Professor of Midwifery at Glasgow University, died before $\mathrm{I}$ was born) and it was evident even to us children what joy the return of this distinguished son and brother brought to this quiet household. The local inhabitants albeit with their customary reserve were also obviously proud of his fame and I was once assured that my father was "well thought of on the shore", a true accolade of approval for those parts.

Other holidays were either of the orthodox seaside variety or alternatively spent in remote farm houses selected usually with reasonable success from advertisements appearing in 'The Times'. On these occasions father seemed to accept contentedly conditions which were often simple if not frankly primitive, although as a hygienist the sanitation must at times have caused him some qualms: The usual family activities, picnics, expeditions and the like seemed to satisfy him and only occasionally and then largely for the benefit of his son's education did we branch out in games of golf or fly fishing. Although rather past games-playing himself he had like all fathers ambitions for his son and time and again and to the acute detriment of his shins sportingly offered himself on the wildest of pitches as the target for inaccurate fast bowling.

Despite the brilliance of his own career as a young man I have ever been grateful that he never gave me the impression that he was expecting the same of me. Those who have been in a similar position will agree that it is not an unqualified blessing to be the son of an outstanding personage. Throughout my school days he was almost submerged 
by his commitments in his dual rolè as an administrator and scientist but he found time to identify himself with my activities as I progressed up the school taking the triumphs and disasters as philisophically as a good father should. I am not going to say that it was not on occasions a help to have a father who was a Governor of the school. Before the start of a school term he would often give me lunch at his Club and those occasions became red-letter days in my life.

After Westminster came Oxford where father had two old friends in Pathology-E. W. Ainley-Walker and George Dreyer and these two undoubtedly facilitated my entry. By now however the sands were running out and there was alack only a year to go. The first symptoms of peptic ulcer had made their appearance while he was in France with the B.E.F. and from that time his family were aware that he suffered continually. Some remission was secured early in the twenties by a gastro-enterostomy performed by Sir W. Arbuthnot Lane but soon the trouble recurred. While I was in my first year and my eldest sister in her 4 th year at Oxford we were summoned one Sunday in haste as father had been admitted to Millbank Hospital after a severe haematemesis. I am unlikely to forget that day; first the search for a friend to take us to London by road as there was a train strike and then at the end of our journey the picture that still remains with me of father exsanguinated and desperately weak. Blood transfusion would have saved his life but this was then unavailable and he died on June 2nd, 1926.

And what do I remember of the man? The portrait included in this issue is a good likeness. Slightly below average height and when in good health perhaps a little portly, it was his fine domed head accentuated by the baldness which commanded attention. Kindly, but often I thought, troubled blue eyes, rather bushy eyebrows and a military moustache complete the picture. A slight rolling of his r's alone portrayed his Scottish origins although for storytelling purposes a Glasgow accent could always be assumed to perfection. His speech was quiet with a well chosen vocabulary and he seldom found it necessary to raise his voice. His manners were impeccable even courtly and his courtesy exemplary. To us children he appeared the fountain of all knowledge and he was undoubtedly well educated beyond his professional qualifications. He was sufficiently fluent in French for speech making and he at least read German without difficulty. He played the piano well and to the great enjoyment of his family. He had inherited from his artist mother a considerable talent for drawing which not only provided a recreation at holiday times but was of immense value to him in recording accurately his microscopic studies. He was a heavy cigarette smoker which was probably unwise in view of his ulcer but he drank very sparingly.

With all his attainments he was I judge a simple man and there was no trace of pomposity in him. His honours and decorations seemed to leave him largely unmoved; indeed I heard him once complain quite bitterly before going out to a full-dress function that he looked " like a Christmas tree".

My mother and father were manifestly devoted to each other and this atmosphere ensured the security of our family life. My mother had deep religious convictions and these I think were matched by my father's and between them they set ùs children such a high standard of principle and conduct as I confess was difficult to emulate at all times. It has been said that my father had no enemies and this might well be true for he was readily approachable and possessed a sympathetic and understanding manner and we seldom heard him speak critically of others. This reputation is especially commendable 
when one realises as I do today that for most of these years the nagging misery of his ulcer was making tremendous demands on his fortitude and self control.

Doubtless like other sons whose fathers have died prematurely I have long regretted that in the time available I did not achieve a greater degree of intimacy with him. This would I think have developed as I became more adult but some measure of Scottish reserve would first have had to be overcome.

It goes without saying that we were immensely proud of him even though in my case it was not till later days that I realised the full extent of his fame. However, what mattered more to us at the time was the fact that he proved himself a tolerant and generous parent who at all times strove to do the best he could for his family and for this we will ever be in his debt.

\title{
REMINISCENCE
}

\author{
Major-General Sir ERNEST COWELL
}

K.B.E., C.B., D.S.O., T.D., D.L., M.D., F.R.C.S., late R.A.M.C. (Retd.)

I FIRST met Sir William Leishman when he came to live in Croydon in the early twenties. Every Saturday morning he was to be seen working in his garden, pruning roses or cutting the lawn. He was a happy family: man. Lady Leishman took an active interest in the local Red Cross, and was a charming and most gracious lady. His three daughters were all successful in their academic careers and his son is to day a distinguished physician. The General, a small, slight figure, was the acme of kindness and courtesy; for instance he gladly accepted my invitation to dine with the officers of the T.A.C.C.S. whjch at that time I was commanding. He came in uniform.

On another memorable occasion, the General took me as his guest to the annual dinner in London, of the Old Students Association of Glasgow University, of which he was that year President. I was given the place of honour and sat at his right hand. When the time came for his speech he said: "I am not going to give you the usual platitudes, stories and reminiscences of our. Alma Mater, but will take you into the future. In a few years you will be flying off to the country for the weekend, travelling miles and miles, in comfort."

Latterly I was the General's doctor; he remained in harness to the end of his life. Actually he did not" "report sick", but Lady Leishman called me in and I immediately took a grave view, recommending admission to Millbank. He demurred but gave in to his wife. Within the hour, an ambulance arrived and I helped carry the stretcher. In a few days, in spite of all that could be done, a very gallant and noble gentlemen passed on. 